\title{
Structural Forms of Feminine Psyche in Scheherazade According to Toni Wolff's Quaternity
}

Mitra Mosavat

Zohre Taebi

Sara Mosavat

Ferdowsi University of Mashhad, Iran

\begin{abstract}
The universality and significance of The Thousand and One Nights is undeniable: the complexity of the book has combined its various literary techniques to create a masterpiece which has been translated by famous figures, and has influenced many writers all around the world. The central figure of The Thousand and One Nights is its female narrator, Scheherazade, whose complex personality has a great potential to be studied. One of psychological theories which can fully present this complexity and multidimensionality is Toni Wolff's quaternity. Wolff, a Swiss analytical psychologist and one of Jung's students, is best known for her paper on four aspects or structural forms of feminine psyche, which are the Mother, the Hetaira, the Amazon, and the Medial. These four aspects, though working independently, form the feminine psyche: if they are put in a balance with each other, the personality is a complete one. The present article is an attempt to apply Wolff's structural forms of feminine psyche in Scheherazade's character: first, the basic tenets of Wolff's quaternity is presented and consequently, her views will be examined in the various stories narrated by Scheherazade, since the four aspects mentioned above are crystalized in women characters of The Thousand and One Nights.
\end{abstract}

Keywords: Feminine Psyche, Scheherazade, The Thousand and One Nights, Toni Wolff.

\section{Introduction}

The Year of Turmoil (first published in 1992), a contemporary novel by the popular Iranian author Abbas Maroufi (1957 present), recounts the sorrowful story of a young woman (called Noushafarin) in the male domineering atmosphere of the novel and her unfulfilled dreams for a happy life. Deprived of her basic feminine needs, Noushafarin is beaten regularly by her husband, which causes her to die in a terrible condition at the end of the story.

Several short stories, plays and novels written by Abbas Maroufi, including the Year of Turmoil, have been analyzed according to psychoanalytic approach particularly. Other approaches (namely the socio-psychoanalytic approach), nonetheless, are applied to his literary pieces. There exist many theses on Maroufi's works, most of which are about his most famous novel, the Symphony of the Dead. Others try to study various works of Maroufi simultaneously, including the Year of Turmoil, from a special point of view (particularly psychoanalytic approach) and in relation to each other. Among these, we can name Analysis of Abbas Maroufi's Works, a thesis written by Hossein Sanayi-Moqaddam which "aims to come by the infrastructures and themes of Maroufi's works, analyzing them deeply and meticulously regarding important fictional elements and new literary theories" $(2009$, p. 6). This thesis analyses some short stories and three novels of Maroufi. Besides, Psychoanalytic Analysis of Maroufi's Works by Mahboubeh Azhari offers a deep "psychoanalytical survey of Maroufi's characters and fictions based on Freud's, and his students' teachings" (2009, p. 11). Khajooyinejad's $A$ Psychoanalytic Study of the Symphony of the Dead, the Year of Turmoil, and Farhad's Body (2010) "examines the characters of these three famous novels of Maroufi, exploring and analyzing their significant mental points (which establish their behaviors)" (p. 6). The last considerable thesis written in this field is Mohammad Yusefi's Sociological Analysis of Character in Two Novels of Maroufi, the Year of Turmoil and the Symphony of the Dead. Taking a sociological point of view, it studies the characters of these two novels, the formation of which sheds light on the problems and atmosphere of society at that time (2012). 
As it is mentioned, most of the works done on the Year of Turmoil are not ascribed to this particular novel, but they try to explore it along with some other works of the author. In addition, they mostly utilize psychoanalytic approach to investigate the depth of this literary work. Despite these numerous studies and analyses undertaken on Maroufi's novel, the Year of Turmoil, one may face a considerable gap in the review of literature: even though this literary piece, and many other novels of the author, can be studied and analyzed from a feminist point of view, no significant efforts have been done to clarify these texts' position from such a viewpoint.

As a result, the researcher set her sights on investigating this novel within a feminist framework, striving to illuminate the wretched conditions of Noushafarin and other female characters struggling in the patriarchal society of novel. In order to shorten the material into a more manageable one (the novel is a long one, having 347 pages), the researcher focused her study on special chapters of the novel. The Year of Turmoil consists of seven chapters, or "nights" as composed by the author. The "nights" with an odd number $(1,3,5$, and 7$)$ are interior monologues of the protagonist, Noushafarin, while the other ones, i.e. the even ones $(2,4$, and 6$)$ are narrated from an omniscient point of view. This paper will handle only the odd "nights", Noushafarin's interior monologues, in order both to deal with a smaller amount of material, and to demonstrate the situations of Noushafarin more effectively, revealing her feminine thoughts from her own perspective. To put it in a nutshell, the present article endeavors to analyze the patriarchal characteristics of the novel's atmosphere, finding Noushafarin's (and other women's) place in such a society.

\section{Definition of Patriarchy and Social Context of the Year of Turmoil}

To gain a better understanding of social condition in the novels, a brief definition of patriarchy and its place in Iranians culture is presented below. The first question one may face here is: what is patriarchy? "Patriarchy applies to a special familial, social, or political structure that is established on a unique system of regulations and values" (Sharabi, 1992, p. 43) in which men dominate women distinctively. From the patriarchal viewpoint, a woman is not considered a creature having rationality and idea. This is a characteristic of mankind to which a woman doesn't belong (Farsani, 2009). "Man needs no definition; he is the norm against which woman is defined as other associated with complaint, weeping, and pain" (Robbins, 2000, p. 2). In almost every society, as Robbins declares, "women are seen as lesser beings, a mode of thought in which man is taken as the norm and the ideal, and woman is his defining other, the being who validates his importance because of her differences from him" (2000, p. 57). Beauvoir also admits the existence of such definitions for a woman:

She is not regarded as an autonomous being. She is simply what man decrees: thus she is called the sex, by which is meant that she appears to male as a sexual being. For him she is sex - absolute sex, no less. She is defined and differentiated with reference to man and not he with reference to her; she is the incidental, the inessential as opposed to his essential. He is the subject, the absolute; she is the other (1997, p. 16).

As Khezri declares, such patriarchal definition has always been accepted in Iranian society and has not been criticized along the history, reproducing domination in all levels of family and society so that the dominant culture is represented in the power. In such a structure, power implies the father as a god using three methods to manage the family: dictatorship (patriarchy), baseless method, or democracy. But as it has been experienced, the management method in Iranian families has mostly been the first one, i.e. (patriarchal) dictatorship (2010). In traditional Iranian families, "father is usually at the top of the power pyramid, the woman regarded as the second sex. And the most common for family members is physical punishment" (Mohammadi-e-Asl, 2002, p. 24). Therefore, a woman functions in the framework of the house, doing house chores and raising children. Little attention is paid to social and outdoor activities of women. Khezri declares that "such conventions originate in our cultures and our cultural beliefs, and they are applied as cruel and hostile behaviors of powerful family members toward the weaker ones, the tools used by men to prove their dominance on women" $(2010$, p. 5).

Khezri continues, "gender injustice has always been present in Iranian history, and recently has reproduced itself in various forms from earlier eras, spreading this inequality not only to families (where it has always existed) but also to social organizations, just like official regulations. Therefore, one can assert that women have not possessed a proper place in Iran's history: men have had the control in their hands, have set the regulations and defined the place of women in various private (family) and public (society) fields in such a way that is under their own control, doing what meets their own advantages" (2010, p.7). 
The Year of Turmoil is set in such a controversial society. The story takes place in Sangsar (a small city in the present province of Semnan) in first Pahlavi's period. Reza Khan's (first Pahlavi's) era was "the period of introducing many Western norms, and modern organizations and technologies like universities, Ministry of justice, trains and railways, administration of registration and statistics, public military service, new educational system, new ideologies (namely nationalism, liberalism, and Marxism), direct communications with West and Europe, and unveiling women" (Doaguyi, 2011, p. 13); however, slight changes were made to the traditional society of Iran especially in smaller cities such as Sangsar where lies the setting of the Year of Turmoil.

According to Abbasi and Mousavi, "the modernization process that was followed during Pahlavi's period didn't make any considerable changes to the ranks, conditions, and rights of Iranian women" (2014, p. 59). Kaar admits this by declaring:

Despite the social changes in 16 years of Reza Khan's ruling period, women's political place did not change officially and practically. For example, voting right was not yet given to women; they gained neither public ranks nor possibility of establishing independent political organizations to defend their own rights (1997, p. 23).

In Hafezian's opinion, absence of independent organizations for women as their representative for achieving rights, fulfilling their needs, and developing their conditions (their entrance into political and social positions let the patriarchal regime of Reza Khan not to take any steps for developing their political conditions (even though Reza Khan himself pioneered some social changes for women) (2010). "Reza Shah opposed any independent political or feminist moves" (Paidar, 1994, p. 102); in his article (2010), Hafezian declares that during Pahlavi era, the government posed formidable obstacles in the path of creation and performance of independent organizations for women because it wasn't advantageous to the genderdifferentiating purposes of its political regime. As Abbasi and Mousavi argue in their article, in the first decades of Reza Khan's period:

Women were besieged by frameworks of the traditional system, playing their only role as mothers or wives (just like earlier periods). Their main function was defined in family. In such a system, whose atmosphere was dominated by unique controversial thoughts, women were known as slaves to men $(2014$, p. 76$)$.

"Unfortunately in such conditions, due to having grown up in this patriarchal culture and being unaware of other situations and thoughts, most of women had accepted such humiliating outlooks about themselves" (Khosro-Panah, 2003, p. 44). In those years, as Abbasi and Mousavi argue, "many marriages were done in bad conditions, in an improper age for women, not based on love but based not defined familial conventions" (2014, p. 78).

Due to the fact that "the sexual politics of the world outside the text and the sexual politics of the world inside the text, however self-evident or disguised, is parts of a continuum of political critique and action in feminist theories" (Robbins, 2000 , p. 14), the social context of the novel was studied, giving a better perspective of social conditions of women in the time when the setting of the novel is made. As mentioned above, although "women are and were able to perform numerous activities from cultural and social ones to training both (female and male) halves of society" (Doaguyi, 2011, p. 11), they have always been regarded as inferior or other in Iran's history (including the Pahlavi era). In such a society, women like Noushafarin are oppressed. As Abbas Maroufi declares in an interview, "there are many women like Nousha in the world, who die little by little before their death or before being killed" (Raha, 2010) by the oppressive society.

To shed light on women's place, the researcher will apply patriarchal conventions to the Year of Turmoil studying Noushafarin's interior monologues or "nights which are psychological turmoil reflecting conflicted relationship in internal levels of Noushafarin's character and happy relations in her deep dreams" (Bizar-Giti, 2013).

\section{Women's dependence on men and their objectification}

Noushafarin (called Nousha in short form) has always been dependent on men: first her father, Colonel Niloofari, after her father's death to Hosseina, her beloved, and to her husband Dr. Massoum. All over the novel, she is depicted in relation to these three men; she even admits that "everyone is a stone thrown by her father" (Maroufi, 1992, p. 13). When his father dies, she falls for a young man called Hosseina to whom she is dependent as well. Such a heavy dependence culminates in Noushafarin's death after hearing the news of her beloved being killed. Upon hearing the news of Hosseina's death from Dr. Massoum, Nousha who has endured her husband's usual beatings for a long time, finds no essence in living, and therefore passes away. Even after her death, she is greatly dependent to men (in the last pages of the novel, i.e. "night" 7), 
representing the continuous dependency of women on male members of society: she (actually, her ghost) asks Bassi, the grandson of Mirza Hassan "not to forget her because she is very lonely in there" (p. 347).

This dependency can be studied in other female characters, too: Nousha's mother, Alieh Khanom undergoes the disease of insecurity after her husband dies:

"After father's death, she became a rabbit, a rabbit that has become one helplessly, that ate in silence, slept in silence, walked in silence, sure thinking about those days when she had been the wife of the most powerful man of Fars" (p. 40).

This is another obvious reflection of female dependence on male members of a patriarchal society: a woman is not endowed with security by herself. She can only find it in men and beside them ("a widowed woman is an apple left underneath the sun": p. 144).

In the Year of Turmoil, female members of the society are objects possessed by male members. The fight between Dr. Massoum and Hosseina over possessing Nousha ends in a romantic disaster: from one hand, Hosseina asks Nousha domineeringly whether she wants to be Dr. Massoum's or his; from the other hand, Dr. Massoum, accidentally informed of the romance between his wife and Hosseina (in Keypoor's tavern), does his utmost to scalp his rival. In public, he spreads the rumor that Hosseina is suffering from leprosy, causing many to die. He even pays some men to find Hosseina and bring the young man alive. After finding the rival, he doesn't wait for the legal execution: as the story unfolds later, Dr. Massoum crucifies Hosseina to a tree (even though, the identity of the crucified man is not surely expressed in the novel: whether it is Hosseina himself or his brother Siavoshan, caught mistakenly by the men Dr. Massoum hired to find Hosseina). Upon hearing this, Nousha who is lying in her deathbed, dies immediately.

In such a society, defining women as inferior creatures lower their entities to sexual means only: most of the male characters of novel are in the habit of ogling women:

"I would go out... I could hear the breath of a man behind me. I shouldn't look back. I would flex myself, keep my chador tight, and walk faster. I could hear a man's breath that would come closer and say: ye damn pretty! " (p. 14).

"I came back and felt some men had come out of their shops. They were eyeing me from top to toe." (p. 24)

"I had forgotten that I'm a girl. At that moment, I was not thinking that when men are staring at you with those handlebar mustaches and those bright eyes, looking from top to toe and from toe to top, with those searching eyes that want to push your chador back by force and swallow your whole body all at once, you feel ashamed, you melt away, you're squeezed in someone's hands falling just like a drop!" (p. 25)

This downgrading of value of women can be best exemplified in the way Captain Khosravi and Mirza Habib Razmara look at Nousha (and other female characters):

"Not taking his look away from me, he drank his tea... Mother said: Nousha! And cast a glance at my thighs angrily. Immediately, I covered them under the skirt, and looked at Captain Khosravi. It seemed that he had ripped my skirt with his eyes and then had stared joyfully." (Ibid. 52)

"[Mirza Habib Razmara] sat down and cast a look at my neck and arms through the opening of my chador, and smiled. I shuddered. That hateful lascivious ogler eyed me from top to toe, and I didn't stand there anymore" (p. 37).

Mirza Habib Razmara can undoubtedly be called the most patriarchal figure of the novel when he declares: "When a woman sets her foot into one's life, one should piss to that life" (p. 38). Downgrading women can also be seen in society's emphasis on female beauty; both male and female characters draw attention to Nousha's (and other women's) beauty:

"Nousha was very pretty, no one was born prettier than her" (p. 336).

"When I understood that I'm beautiful, I was three; I knew it was a pleasant thing" (p. 340).

"Her name was Afsar; she was very beautiful. She had big brown eyes like yours. Tall and beautiful" (p. 45). 
Objectification of women is abhorred by Nousha whose life lacks love and affection:

"This butterfly [Massoum] sleeps beside me all nights without knowing what love is. Whenever he wants, he sips the syrup of my fusty flower, then tired and exhausted, turns his back on me and sleeps." (p. 32)

"Why are women so miserable to wait all the time? How selfish men are! Seems like they want to buy something cheap, they look at you but retreat" (p. 181).

What's more, male disregarding female is manifested in numerous scenes of harsh beating depicted along the story. Beating, one of the most obvious signs of patriarchy (Afshar, 1998), is a regular habit in Nousha's life. Despite his longtime education in Europe, Dr. Massoum, a symbol of open-mindedness and the educated class of society, is not exonerated from such patriarchal behaviors. Establishing an atmosphere of fear and intimidation along with regular swearing (attributing bad words to Nousha, and even her parents) is a part of his personality:

"Massoum said: ye damn bitch!" (Maroufi, 1992, p. 14)

"He took the hand gun out, hitting me in the head in a way that my scalp was being skinned" (p. 16).

"I was afraid she had heard Massoum's shouts. Did she know that he beats me? I said: mother, he beats me with the stock of gun. It was a long time! He would swear to father, was always drunk" (p. 20).

"Take your hand gun and let go of your complexes, why are you torturing me to death? He hit me in the chest" (p. 59).

"The hand gun hits were repetitions of sleeping in the morning when you have no energy, you hear everything, but can't move" (p. 60).

"It was not perhaps related to the injuries on my body, to the ecchymosis on my arms, or to the pain I felt in my neck, my chest and my back, nor to Hosseina. It was the suffering of all women: when they have grown up, and couldn't wear the clothes they used to wear in the past, the old clothes that were tight now, they had to wear shirts, and if they objected, Massoum would say: don't you argue with me, ye bitch!" (p. 259)

Colonel Niloofari (Nousha's father) too casts women's physical weakness in their teeth occasionally, sometimes in reality and sometimes in Nousha's nightmares:

"Father was exploding of anger... he found his walking stick and came to me. Lifted it to hit me but I ducked" (p. 190).

Once, Nousha has a nightmare in which her father slaps her mother in the face. Even Hosseina sometimes shows such behaviors, though in a milder way:

"I put my hands round his neck, but he took them away from his shoulders and threw me away: get out!" (p. 277)

\section{Internalization of patriarchal conventions by women, and their deprivation of feminine needs}

Regarding Nousha's nightmare about her mother's being beaten by her father, it is clearly seen that patriarchy has penetrated to the mind and the unconscious of women, too; they have internalized the conventions of a patriarchal society:

"My mother [Zobeydeh Khatoon] always says one should not pay too much attention to women, they'd get cheeky" (p. 142).

"When I got married, I was not informed. After the marriage, they told me so. In our city, they don't ask the girl's permission for marriage" (p. 188).

"I said: God forbid the day a woman wants to shout at a man" (p. 206).

This internalization may be the reason why men are depicted as fearful and dominant creatures in the protagonist's unconscious imagery: 
"The gallows tree had a long shadow. Frightening and bizarre. The shadow of a man who has opened his legs in the light of a torch, who is standing on top of one's body... something like the voice of hiccups of a drunken man which is repeated in fatigue of the big watch on top of City Council Building" (p. 11).

Apparently, Nousha is afraid of the dominant patriarchal conventions in her society. Many images she uses in the novel have mentioned men or some notions attributed to them, which (if not always showing her being frightened of men,) at least capture the total domination of men in the atmosphere of the novel:

"I thought the fish have become fish because of their fear of mankind, searching safety at the bottom of water. But even there, they are not safe" (p. 63).

In contrast, the images dealing with picture of women echo their helplessness and misfortune in a total male world:

"I could hear the sound of a woman's cry, sitting alone on the third stair of her father's house, out of hunger or perhaps out of cold... with coarse hands, a frozen face, and tearful eyes, living just in her own memory" (p. 12).

"From time to time I felt that the whole world rotates around a male philosophy, that men become husbands of women, if possible, make them bear a child and if not, make them cry. A woman is a passive indecisive entity whose bravery men destroy to prove their own superiority. It was a big match in which a man must win" (p. 64).

"I cried for all the girls that are ashamed of themselves in their solitude, and later hate themselves so much that finally become just a crust, like an empty tree, and one day they know they have no feeling in their body; all their body and soul is that very crust, and they don't know what they're living for" (p. 157).

The female characters of novel are categorized by Nousha as either "playthings for Captain Khosravi or carpet weaving spiders, or helpless creatures left alone on the stairs of their father's house". To the end of the sentence, she adds: "Who cares?" (p. 64) She is right; actually, no one cares about the state of these women who (like Nazoo) are sexual playthings for men, labeled as lewd. Others (like Keshvar or Dr. Massoum's Mother, Zobeydeh Khatoon) have spent all their life doing house chores and raising children without even having the permission of going out, cherishing their conditions:

"He said his mother [Zobeydeh Khatoon] is a housewife, living alone for a long time, struggling to raise her children with nothing just by weaving woolen cloth" (p. 171).

"Couldn't I remember the girl (Keshvar) who was weaving a carpet just like a spider, dangling on its warps and woofs in white, crimson, green, blue and other colors, satisfied with the fog or the rain, and with the ladder which took her to our house?" (p. 14)

As implied, the last category includes women who, like Nousha and her mother Alieh Khanom, undergo depression in search of a lost love.

In the male-dominated atmosphere of the Year of Turmoil, women are deprived of their most basic feminine needs: Dr. Massoum asks Nousha to wear his worn-out shirts and clothes instead of dresses and skirts:

"He said: what's wrong with my shirt? I said: I'm a woman. I want to wear dresses. He said: clothes are clothes. No difference. Besides, when I like you wearing them, why do you insist on wearing colorful skirts? " (p. 142)

Nousha is depressed, oppressed and, lonely: shall she "tolerate the burdens imposed on all women?" (p. 22) Not having someone to talk to affects Nousha with depression gradually:

"I had no one to talk to, to talk about Hosseina. Someone to whom I could say that I love Hosseina, say do you understand? Do you know what love is? I don't think so. No one knows how I feel, nobody. I was very lonely with so many unspeakable pains in my heart" (p. 175).

Not only her vital need for a companion (a basic feminine one) is not met by Dr. Massoum, but also it is worsened: he forbids any communication between his wife and Keshvar, their neighbor, even though they just used to talk from above the walls between their houses. Lack of a companion drowns Nousha in her hallucinations; deprived of her female needs, 
she talks to her beloved, Hosseina, in her dreams and daydreams. This may be regarded as a symbolic manifestation of patriarchy: women, not understood by their unique feminine characteristics, shall not be cherishing these specialties; instead, they should make every effort to become a copy of the male members. Here, one may be reminded of Colonel Niloofari who had always wanted to have a son, but after all, his wife gave birth to a girl, Nousha. Still, he calls her "Nousha, my son!" (p. 22)

Female characters of the novel are not allowed of participating in social activities such as education, going out alone, and even (in very rigid cases) standing on the balcony:

"I want to go to school. He said: it's not necessary. What you have learned till now is enough." (p. 169)

"I said: why should somebody follow me like a shadow whenever I go out? Mother came closer and said: what? Would your father let me, his wife, go out of the house alone? Now, his daughter goes out by herself? I wouldn't let you!" (p. 22)

"Massoum told me to stay indoors and emphasized that I do not appear on the balcony. Not at all. And said: go in right now!" (p. 155)

Even though as a child, Nousha is unaware of this patriarchy ("When I was a child, I thought everything is mine. Everything is created for my joy. Sky, earth, father, mother, trees, horses, carriages, and even those sparrows are made for my entertainment" p. 68), when she grows up, she confronts its conventions feeling depressed as all those entertainments "are taken away one by one" (p. 68) so that finally, she owns nothing:

"What do I have? Do I clean and cook all the day to live by myself? What do I have?" (p. 141)

\section{Conclusion}

In the Year of Turmoil, male dominance over the female members of the society is quite clear. The protagonist's dependence on men, particularly his father and his beloved, can be seen all over the story. This dependency could be studied in other female characters like Nousha's mother, Alieh Khanom, who undergoes the disease of insecurity after the death of her husband. The female characters of the Year of Turmoil are defined by their relation to men. Moreover, they are nothing more than sexual means, objects which can be possessed whenever they desire. This objectification is represented even in physical punishment. Men, particularly Dr. Massoum (though representing the open-minded class of society) have a regular habit of beating women. The controversial notions of patriarchy have been accepted by women, too. Even the imagery used by the protagonist reflects obvious signs of male domination in the atmosphere of the novel. Female characters of the Year of Turmoil are oppressed sorrowful creatures, worn out in their houses, deprived of social activities and education, deprived of their own female needs even. Further research and analysis can be done on the chapters ("nights" 2, 4, and 6) and the characters the researcher missed due to lack of time, and broadness of topic.

\section{References}

[1] Abbasi, S., \& Mousavi, M. (2014). The Status of Iranian Women during the Pahlavi Regime (from 1921 to 1953). Women Studies, 5(1), 59-82.

[2] Afshar, H. (1998). Islam and Feminisms: an Iranian Case Study. Basingstoke: Palgrave Macmillan.

[3] Azhari, M. (2010). Psychoanalytic Analysis of Maroufi's Works (M.A.), Al-Zahra University, Tehran.

[4] Beauvoir, S. d. (1997). The Second Sex. London: Vintage.

[5] Bizar-Giti, M. (2013, December, 14). Proximity of Language and Time in The Year of Turmoil [Web log post]. Retrieved from http://www.qognoos.ir/ShowReviews.aspx?ReviewID=583

[6] Doaguyi, F. (2011). Process of Formation of Woman's New Identity in Iran: from Nasseri Era to First Pahlavi (M.A.), Payam-e-Noor University of Tehran, Tehran.

[7] Farsani, S. T. (2009). Women's struggle in Qadjar Era: Individuality, Conventional World, and Making through It. History of Iran and Islam (Scientific Periodical of Alzahra University), 19(2).

[8] Hafezian, M. H. (2010). Women's Organizations in Iran During Pahlavi Era. Political Studies, Winter(2), 33-50. 
[9] Kaar, M. (1997). Political Rights of Iranian Women. Tehran: Roshangaran and Women Studies.

[10] Khajooyinejad, L. (2010). A Psychoanalytic Study of the Symphony of the Dead, the Year of Turmoil, and Farhad's Body (M.A.), Sistan Balouchestan University, Sistan Balouchestan.

[11] Khezri, Z. (2010). A Survey of Roots of Patriarchal Structure in Iranian Family. (M.A.), Tabriz University, Tabriz.

[12] Khosro-Panah, M. H. (2003). Goals and Struggles of Iranian Woman. Tehran: Payam-e-Emrooz.

[13] Maroufi, A. (1992). The Year of Turmoil (Sal-e-Balva). Tehran: Gardoon Publications.

[14] Mohammadi-e-Asl, A. (2002). Gender and Participation: An Introduction to Sociology of Political Participation of Iranian Women. Tehran: Roshangaran and Women Studies.

[15] Paidar, P. (1994). Women and the Political Process in the Twentieth Century Iran. Cambridge: Cambridge University Press.

[16] Raha. (2010, October, 8). An Interview with Abbas Maroufi [Web log post].Retrieved from http://www.forum.98ia.com/t93662.html

[17] Robbins, R. (2000). Literary Feminisms. New York: Saint Martin's press.

[18] Sanayi-Moqaddam, H. (2009). Analysis of Abbas Maroufi's Works. (M.A.), Mohaqqeq Ardabili University, Ardabil.

[19] Sharabi, H. (1992). Neopatriarchy: A Theory of Distorted Change in Arab Society. Oxford: Oxford University Press.

[20] Yusefi, M. (2012). Sociological Analysis of Character in Two Novels of Maroufi, the Year of the Turmoil and the Symphony of the Dead (M.A.), Birjand University, Birjand. 